\title{
Fatty acid profile of Cystoseira C. Agardh (Phaeophyceae, Fucales) species from the Tunisian coast: Taxonomic and nutritional assessments
}

\section{Perfil de ácidos grasos de especies de Cystoseira C. Agardh (Phaeophyceae, Fucales) de la costa tunecina: Evaluaciones taxonómicas y nutricionales}

\author{
Cyrine Bouafif $^{1 *}$, Chokri Messaoud ${ }^{2}$, Mohamed Boussaid $^{2}$, Habib Langar ${ }^{1}$ \\ ${ }^{1}$ Université de Tunis El Manar, Faculté des Sciences de Tunis, Département de Biologie, 2092, Tunis, Tunisia. \\ 2 University of Carthage, National Institute of Applied Science and Technology, Department of Biology, Centre \\ Urbain Nord, BP 676, 1080, Tunis, Tunisia. \\ * Corresponding author. E-mail: bouafif.cyrine@gmail.com
}

\begin{abstract}
A screening of the total lipids and fatty acids (FAs) of 11 brown algae species of the genus Cystoseira (Phaeophyceae, Fucales) from the Tunisian coast is presented and discussed. Cystoseira species showed low total lipid content, ranging from 19.8 to $68.2 \mathrm{mg} \cdot \mathrm{g}^{-1} \mathrm{dry}$ weight. Fourteen major FAs were detected in the lipid extract of Cystoseira. The FA profile of lipid extracts was characterized by high amounts of saturated FAs (SFAs) ranging from $40.51 \%$ to $57.91 \%$ of total FAs, with predominance of the lipid fraction of palmitic acid ( $>30 \%$ of total FAs). The arachidonic acid (C20:4n-6) levels were found to be significantly high, ranging from $8 \%$ to $16 \%$ of total FAs. Multivariate analyses of FA composition showed low geographic differentiation, providing further evidence of intraspecific diversity. Cystoseira crinita, Cystoseira schiffneri, Cystoseira amentacea var. stricta, and Cystoseira sedoides stood out for their low polyunsaturated fatty acid (PUFA)/SFA ratios, low n-6/n-3 PUFA ratios, high unsaturation, and low atherogenicity and thrombogenicity indices, suggesting high nutritional value.
\end{abstract}

Key words: marine algae, Cystoseira, fatty acids, polyunsaturated fatty acids, Tunisia.

RESUMen. Aquí se presenta y discute un análisis de los lípidos totales y ácidos grasos (AG) de 11 especies de algas pardas del género Cystoseira (Phaeophyceae, Fucales) de la costa de Túnez. Las especies de Cystoseira mostraron un contenido lipídico total bajo que osciló entre 19.8 y $68.2 \mathrm{mg} \cdot \mathrm{g}^{-1}$ de peso seco. Se detectaron 14 AG mayoritarios en el extracto lipídico de Cystoseira. El perfil de AG de los extractos de lípidos estuvo caracterizado por altas cantidades de AG saturados (AGS) que variaron de 40.51\% a 57.91\% del total de AG, con predominio de la fracción lipídica del ácido palmítico (>30\% del total de AG). Los niveles de ácido araquidónico (20:4n-6) fueron significativamente altos, y variaron entre el $8 \%$ y el 16\% del total de los AG. Los análisis multivariados de la composición de AG mostraron baja diferenciación geográfica, lo que aporta más evidencia de diversidad intraespecífica. Cystoseira crinita, Cystoseira schiffneri, Cystoseira amentacea var. stricta y Cystoseira sedoides destacaron por presentar bajas relaciones de ácidos grasos polinsaturados (PUFA)/AGS y PUFA n-6/n-3, alta insaturación y bajos índices de aterogenicidad y trombogenicidad, lo que sugiere un alto valor nutricional.

Palabras clave: algas marinas, Cystoseira, ácidos grasos, ácidos grasos polinsaturados, Túnez.

\section{INTRODUCTION}

In brown algae, fatty acids (FA) are known to have important properties. They constitute a source for pheromone biosynthesis and have antimicrobial (Rosell and Srivastava 1987), anti-inflammatory (Calder 2006, Kumari et al. 2010), and antioxidant (Kumar et al. 2011) properties. These metabolites are also known for their ability to prevent heart disease and inhibit tumor progression (Pereira et al. 2012). In situ, brown algae use FA-derived compounds as a chemical defense (Pohnert and Boland 2002, Barre et al. 2004), i.e., to deter herbivores (Schnitzler et al. 2001). Fatty acids (FAs) and lipid components have scarcely been studied for their chemotaxonomic implications in macroalgae (Khotimchenko et al. 2002, Galloway et al. 2012, Kumari et al. 2013).

Among brown algae, Cystoseira (Ochrophyta, Phaeophyceae) is one of the most widely distributed genera of the

\section{INTRODUCCIÓN}

Se sabe que los ácidos grasos (AG) de las algas pardas tienen propiedades importantes. Son una fuente para la biosíntesis de feromonas y tienen propiedades antimicrobianas (Rosell y Srivastava 1987), antinflamatorias (Calder 2006, Kumari et al. 2010) y antioxidantes (Kumar et al. 2011). También se reconoce la capacidad de estos metabolitos para prevenir cardiopatías e inhibir la progresión de tumores (Pereira et al. 2012). In situ, las algas pardas usan compuestos derivados de los AG como defensa química (Pohnert y Boland 2002, Barre et al. 2004), i.e., para desalentar a los herbívoros (Schnitzler et al. 2001). Existen escasos estudios sobre las implicaciones quimotaxonómicas de los componentes lipídicos y los AG en las macroalgas (Khotimchenko et al. 2002, Galloway et al. 2012, Kumari et al. 2013).

De las algas pardas, Cystoseira (Ochrophyta, Phaeophyceae) es uno de los géneros del orden Fucales con mayor 
Fucales order in the Mediterranean (Amico 1995, Pellegrini et al. 1997). In the Mediterranean Sea, the Cystoseira are canopy-forming algae that dominate the rocky infralittoral zone. This genus comprises 42 species distributed mainly in the Mediterranean Sea and the adjacent Atlantic Ocean (Guiry and Guiry 2016).

A great diversity of Cystoseira is present along the Tunisian coast. According to Bouafif et al. (2014, 2016), 31 species are present on the Tunisian littoral, but little information about the chemical composition of the algae from this region has been published (Frikha et al. 2011). Moreover, it is hard to distinguish species and varieties of the genus Cystoseira due mainly to the high morphological plasticity of the taxa and to the active process of speciation of the genus (Ercegovič 1952, Amico 1995). Classification of this genus based on chemical compounds, such as sterols and terpenes, started in the 1990s (Piattelli 1990, Amico 1995). Metabolites isolated from the Cystoseira species have been used as chemotaxonomic markers (Amico 1995, Pellegrini et al. 1997). Total lipid and FA profiles vary significantly among Cystoseira species (Vizetto-Duarte et al. 2015) and might be useful for taxonomic purposes (Galloway et al. 2012). Moreover, the nutritional value of Cystoseira FAs has never been studied in Tunisia. However, some works have been done on the nutritional quality of FAs of some Cystoseira species in the Mediterranean (Ragonese et al. 2014), the Atlantic (Vizetto-Duarte et al. 2015), and the Indian Ocean (Kumari et al. 2010, Kumari et al. 2013).

The aim of this paper is to assess the composition of FAs extracted from 11 Cystoseira species (Fig. 1) growing along the Tunisian coast (i) to evaluate the efficiency of Cystoseira FAs as chemotaxonomic markers associated with criteria performed on the morphological diversity of Tunisian Cystoseira taxa (Bouafif et al. 2014, 2016) and (ii) to estimate the nutritional characteristics of one of the most abundantly available brown macroalgae in the Mediterranean. To the best of our knowledge, this is the first report on the FA profile of some endemic Mediterranean species of Cystoseira.

\section{MATERIALS AND METHODS}

\section{Fieldwork and algal samples}

Eleven species and infraspecific taxa of the genus Cystoseira were collected in the upper intertidal zone between 0.5 and $2.0 \mathrm{~m}$ depth in October 2014: Cystoseira amentacea var. stricta, Cystoseira barbata, Cystoseira compressa, Cystoseira crinita, Cystoseira elegans, Cystoseira foeniculacea, Cystoseira foeniculacea f. latiramosa, Cystoseira foeniculacea $\mathrm{f}$. tenuiramosa (from 2 localities), Cystoseira schiffneri, Cystoseira sauvageauana, and Cystoseira sedoides (Figs. 1, 2). Specimens were transported to the laboratory distribución en el Mediterráneo (Amico 1995, Pellegrini et al. 1997). En el mar Mediterráneo, las algas del género Cystoseira son formadoras de dosel que dominan la zona infralitoral rocosa. Este género está constituido por 42 especies que se distribuyen principalmente en el mar Mediterráneo y en el océano Atlántico adyacente (Guiry y Guiry 2016).

Una gran diversidad de Cystoseira está presente en la costa de Túnez. De acuerdo con Bouafif et al. (2014, 2016), hay 31 especies sobre el litoral de Túnez, pero existe poca información publicada sobre la composición química de las algas de esta región (Frikha et al. 2011). Además, es difícil distinguir entre las especies y variedades de Cystoseira debido, principalmente, a la alta plasticidad morfológica de los taxones y al proceso activo de especiación del género (Ercegovič 1952, Amico 1995). La clasificación de este género basada en componentes químicos, como los esteroles y los terpenos, inició en la década de los noventa (Piattelli 1990, Amico 1995). Los metabolitos aislados de las especies de Cystoseira han sido utilizados como marcadores quimiotaxonómicos (Amico 1995, Pellegrini et al. 1997). Los perfiles de lípidos totales y AG varían significativamente entre las especies de Cystoseira (Vizetto-Duarte et al. 2015) y podrían ser útiles para propósitos taxonómicos (Galloway et al. 2012). Por otra parte, el valor nutricional de los AG del género Cystoseira no se ha estudiado en Túnez. No obstante, existen algunas investigaciones de los AG de algunas especies de Cystoseira en el mar Mediterráneo (Ragonese et al. 2014), el océano Atlántico (Vizetto-Duarte et al. 2015) y el océano Índico (Kumari et al. 2010, Kumari et al. 2013).

El propósito de este trabajo es determinar la composición de los AG extraídos de 11 especies del género Cystoseira (Fig. 1) que crecen a lo largo de la costa de Túnez para (i) evaluar la eficacia de los AG de Cystoseira como marcadores quimiotaxonómicos asociados a criterios aplicados a la diversidad morfológica de los taxones de Cystoseira de Túnez (Bouafif et al. 2014, 2016) y (ii) estimar las características nutricionales de una de las algas pardas que más abunda en el mar Mediterráneo. Hasta donde sabemos, este es el primer estudio del perfil de los AG de algunas especies de Cystoseira endémicas del mar Mediterráneo.

\section{MATERIALES Y MÉTODOS}

\section{Trabajo de campo y muestras de algas}

Se recolectaron 11 especies taxones infraespecíficos del género Cystoseira en la parte superior de la zona intermareal, entre 0.5 y $2.0 \mathrm{~m}$ de profundidad, en octubre de 2014: Cystoseira amentacea var. stricta, Cystoseira barbata, Cystoseira compressa, Cystoseira crinita, Cystoseira elegans, Cystoseira foeniculacea, Cystoseira foeniculacea f. latiramosa, Cystoseira foeniculacea f. tenuiramosa (de 2 sitios), Cystoseira schiffneri, Cystoseira sauvageauana y Cystoseira sedoides (Figs. 1, 2). Los especímenes se transportaron al laboratorio en una nevera portátil. Después de limpiar los especímenes cuidadosamente 


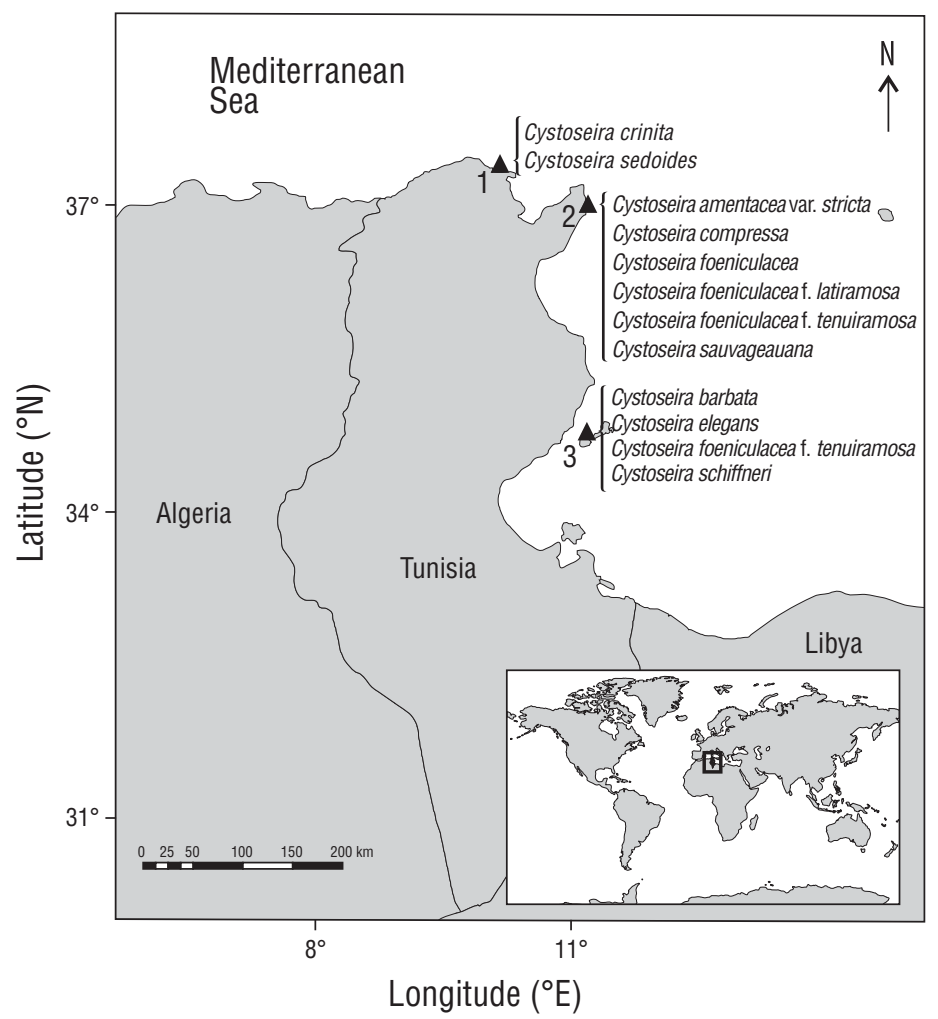

Figure 1. Location of sampling sites and list of species collected at each site: 1, Cap Zebib $\left(37^{\circ} 16^{\prime} 9.15^{\prime \prime} \mathrm{N}, 10^{\circ} 3^{\prime} 59.18^{\prime \prime} \mathrm{E}\right)$; 2 , Kelibia

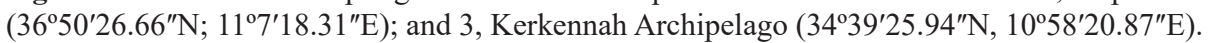

Figura 1. Localización de los sitios de muestreo y lista de las especies recolectadas en cada sitio: 1, Cap Zebib (37 $\left.16^{\prime} 9.15^{\prime \prime} \mathrm{N}, 10^{\circ} 3^{\prime} 59.18^{\prime \prime} \mathrm{E}\right)$;

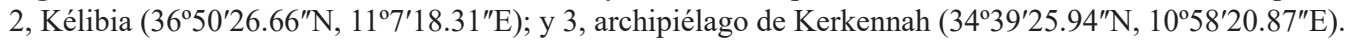

in an icebox. Species were identified by morphological examination according to specialized literature on the genus Cystoseira (Hamel 1931-1939, Ercegovič 1952, Gómez-Garreta et al. 2001) after careful cleaning that removed epiphytes and sand. A representative specimen of each species was deposited in the Herbarium of the Faculty of Sciences of Tunis (Tunisia) in the Department of Biology. Samples of each freshly collected and identified species were rinsed with distilled water, dried in an oven at $30^{\circ} \mathrm{C}$ for $72 \mathrm{~h}$, then stored in darkness and kept in the dry at room temperature until further use. Each sample consisted of a mixture of 2 to 4 infertile adult thalli. The same stage of development of thalli was considered to pass up unpredictability linked to the physiological state of individuals, and entire algal thalli were considered when determining total lipids and FAs to avoid any intrathallus variation among the species (Connan et al. 2007, Abdala-Díaz et al. 2014).

\section{Extraction and estimation of total lipids}

Five grams of each sample were pulverized in liquid nitrogen with a mortar and pestle. Extraction was done by the chloroform-methanol method according to Nomura et al. (2013). The obtained organic phase was para remover las epifitas y la arena, las especies fueron identificadas mediante la examinación morfológica de acuerdo con la literatura especializada sobre el género Cystoseira (Hamel 1931-1939, Ercegovič 1952, Gómez-Garreta et al. 2001). Un espécimen representativo de cada especie fue depositado en el Herbario de la Facultad de Ciencias de Túnez (Túnez) en el Departamento de Biología. Las muestras de cada especie recién recolectadas e identificadas fueron enjuagadas con agua destilada, secadas en un horno a $30^{\circ} \mathrm{C}$ por $72 \mathrm{~h}$ y conservadas en la oscuridad, en seco y a temperatura ambiente hasta su uso. Cada muestra consistió en una mezcla de 2-4 talos adultos infértiles. Se consideró la misma etapa de desarrollo en los talos para eliminar la incertidumbre relacionada con el estado fisiológico de los individuos, y los talos algales enteros se consideraron en la determinación de los lípidos totales y los AG para evitar variaciones intratalo entre las especies (Connan et al. 2007, Abdala-Díaz et al. 2014).

\section{Extracción y estimación de los lípidos totales}

Se pulverizaron $5 \mathrm{~g}$ de cada muestra en un mortero con nitrógeno líquido. Para la extracción, se usó el método con cloroformo y metanol de acuerdo con Nomura et al. (2013). La fase orgánica obtenida fue sometida a un análisis de lípidos totales y ésteres metílicos de AG (EMAG). El contenido de 
subjected to total lipid and FA methyl esters (FAME) analysis. Total lipid content was determined gravimetrically and expressed as milligrams per gram of dry weight (DW) after evaporation of the solvent on a rotary vacuum evaporator at $30^{\circ} \mathrm{C}$. All analyses were performed in triplicate.

\section{Preparation of fatty acid methyl esters}

FAs were transformed to their FAME by transmethylation in accordance with Prevot and Mordret (1976), with slight modifications. Briefly, $1.0 \mathrm{~mL}$ of hexane was added to $10 \pm 1 \mathrm{mg}$ of total lipid aliquot and $0.2 \mathrm{~mL}$ $2 \mathrm{~N} \mathrm{NaOH}$ in $\mathrm{MeOH}$, vortexed for $10 \mathrm{~s}$, then heated at $55^{\circ} \mathrm{C}$ for $30 \mathrm{~s}$. Then $0.2 \mathrm{~mL} 2 \mathrm{~N} \mathrm{HCl}$ in $\mathrm{MeOH}$ was added and vortexed for $60 \mathrm{~s}$. The mixture was centrifuged (Sorvall RC5C instruments, Fiberlite F21-8x50y rotor, Thermofisher, USA) at $1,000 \times \mathrm{g}$ for $5 \mathrm{~min}$. The upper hexane layer containing FAME was subjected to lípidos totales se determinó gravimétricamente y se expresó en miligramos por gramo de peso seco (PS) después de evaporar el solvente sobre un evaporador rotatorio al vacío a $30^{\circ} \mathrm{C}$. Todos los análisis fueron realizados por triplicado.

\section{Preparación de los ésteres metílicos de ácidos grasos}

Los AG fueron transformados en sus EMAG por medio de transmetilación siguiendo el método de Prevot y Mordret (1976), con algunas modificaciones. Brevemente, se agregó $1.0 \mathrm{~mL}$ de hexano a $10 \pm 1 \mathrm{mg}$ de la alícuota de los lípidos totales y $0.2 \mathrm{~mL}$ de $2 \mathrm{~N} \mathrm{NaOH}$ en $\mathrm{MeOH}$, se colocó en un agitador vórtice por $10 \mathrm{~s}$ y después se calentó a $55^{\circ} \mathrm{C}$ por $30 \mathrm{~s}$. A continuación, se agregaron $0.2 \mathrm{~mL}$ de $2 \mathrm{~N} \mathrm{HCl}$ en $\mathrm{MeOH}$ y se colocaron en un agitador vórtice por $60 \mathrm{~s}$. Se centrifugó la mezcla (Sorvall RC5C instruments, rotor Fiberlite F21-8x50y, Thermofisher, EUA) a $1,000 \times \mathrm{g}$ por $5 \mathrm{~min}$. La capa superficial del hexano que contenía los EMAG fue sometida a un estudio de cromatografía de gases acoplada a espectrometría de masas.
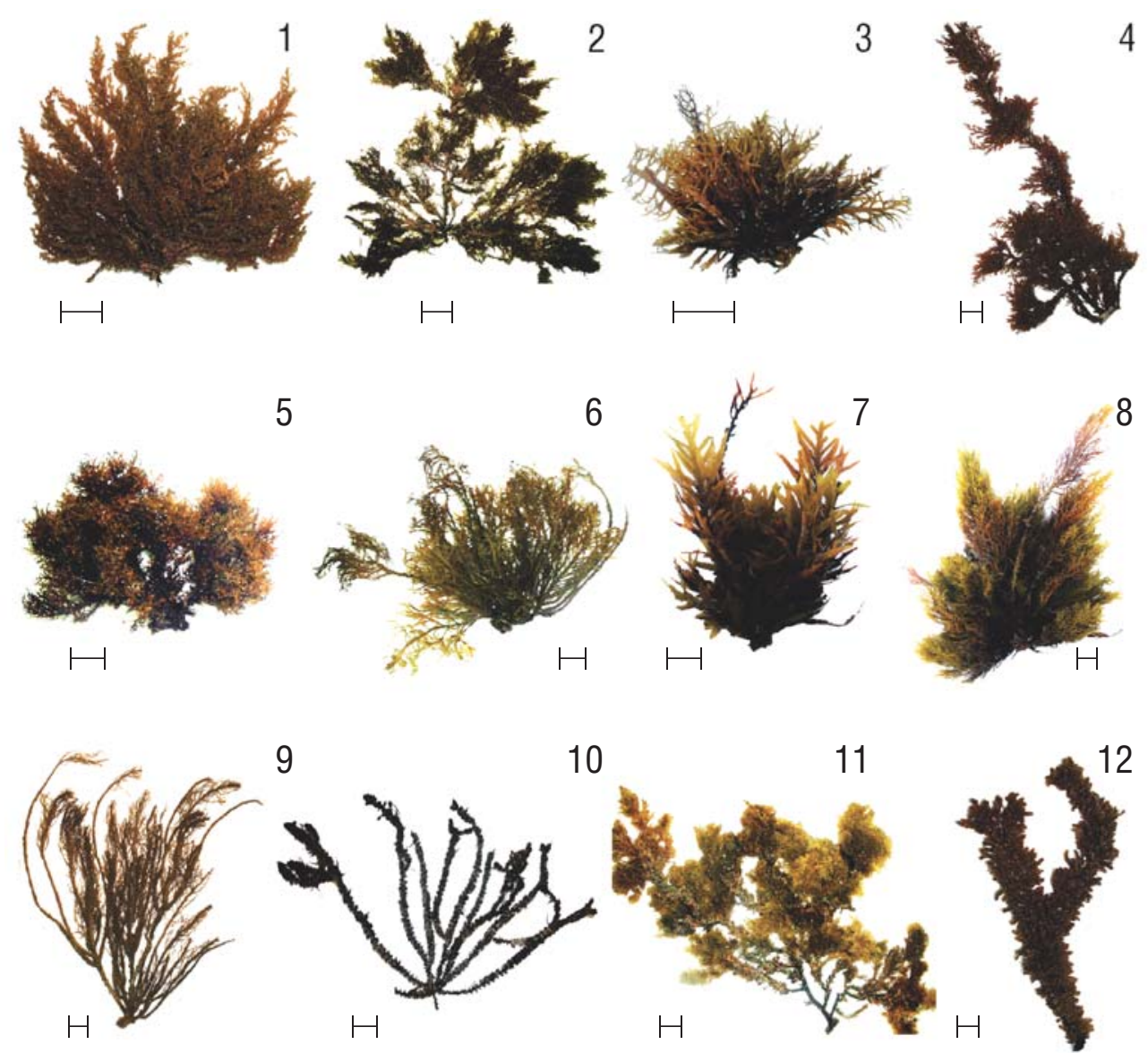

10

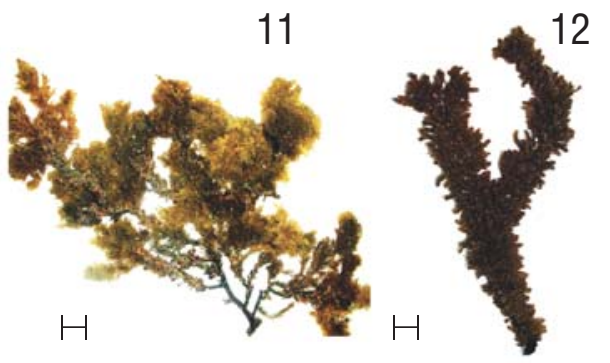

Figure 2. Cystoseira species collected along the Tunisian coast $(\mathrm{scale} b \mathrm{bar}=1 \mathrm{~cm})$.

Figura 2. Especies de Cystoseira recolectadas a lo largo de la costa tunecina (barra de escala =1 cm).

1, Cystoseira amentacea var. stricta; 2, Cystoseira barbata; 3, Cystoseira compressa; 4, Cystoseira crinita; 5, Cystoseira elegans; 6, Cystoseira foeniculacea; 7, Cystoseira foeniculacea f. latiramosa; 8, Cystoseira foeniculacea f. tenuiramosa (North); 9, Cystoseira foeniculacea f. tenuiramosa (South); 10, Cystoseira schiffneri; 11, Cystoseira sauvageauana; 12, Cystoseira sedoides. 
gas chromatography coupled with mass spectrometry analysis.

\section{Gas chromatography coupled with mass spectrometry analysis}

Gas-chromatography coupled with mass spectrometry (GC-MS) was used to establish the FA profile of the lipid fraction. GC-MS analysis was done on an Agilent 7890A chromatograph equipped with an Agilent 5975C inert Mass Selective Detector and a HP-5 MS fused-silica capillary column $(30.0 \mathrm{~m} \times 0.25 \mathrm{~mm}, 0.25 \mu \mathrm{m}$ film thickness). The column temperature regime was $150^{\circ} \mathrm{C}$ for $2 \mathrm{~min}$, followed by $230^{\circ} \mathrm{C}$ at $4^{\circ} \mathrm{C} \cdot \mathrm{min}^{-1}$ and $230^{\circ} \mathrm{C}$ for $5 \mathrm{~min}$. Helium was used as a carrier gas at a rate flow of $0.8 \mathrm{~mL} \cdot \mathrm{min}^{-1}$. Mass scan range was $50-550 \mathrm{amu}$ at $70 \mathrm{eV}$ and scan velocity was 2.86 scans per second. One microliter of each sample was injected. Identification of FAME was carried out by comparing their retention times with those of FAME standards and by comparing their mass spectra with those recorded in the NIST08 and W8N08 mass spectral libraries.

\section{Determining lipid quality indices}

For the unsaturation index (UI), the molar proportion (percentage) of each FA was multiplied by the number of double bonds after addition:

$\mathrm{UI}=$ Sum $\%$ unsaturated acids $\times$ number of double bonds. (1)

To assess the nutritional and lipid quality of Cystoseira species, health lipid indices (indices of atherogenicity [IA] and thrombogenicity [IT]) were estimated in accordance with the Ulbricht and Southgate (1991) method based on FA composition:

\section{Análisis de cromatografía de gases acoplada a espectrometría de masas}

La cromatografía de gases junto con la espectrometría de masas (CG-EM) fue utilizada para establecer el perfil de los AG de la fracción lipídica. El análisis CG-EM se realizó con un cromatógrafo Agilent 7890A equipado con un detector selectivo de masas Agilent 5975C inert-MSD y una columna capilar de sílice fundida HP-5 MS $(30.0 \mathrm{~m} \times 0.25 \mathrm{~mm}$, $0.25 \mu \mathrm{m}$ de grosor de película). El régimen térmico de la columna fue el siguiente: $150{ }^{\circ} \mathrm{C}$ por $2 \mathrm{~min}$, seguido por $230{ }^{\circ} \mathrm{C}$ a $4{ }^{\circ} \mathrm{C} \cdot \mathrm{min}^{-1}$ y finalmente $230{ }^{\circ} \mathrm{C}$ por $5 \mathrm{~min}$. Se usó helio como el gas portador a un flujo de $0.8 \mathrm{~mL} \cdot \mathrm{min}^{-1}$; el rango del detector de masas fue de 50-550 uma a $70 \mathrm{eV}$ y la velocidad de detección fue de 2.86 detecciones por segundo. Se inyectó $1 \mu \mathrm{L}$ de cada muestra. Los EMAG fueron identificados por medio de la comparación de sus tiempos de retención contra los tiempos estándares de EMAG y la comparación de sus espectros de masas con aquellos registrados en las bibliotecas de espectros de masas NIST08 y W8N08.

\section{Determinación de los índices de calidad de los lípidos}

Para el índice de instauración (UI), se sumaron las proporciones molares (porcentajes) de cada AG y se multiplicaron por el número de enlaces dobles:

$$
\begin{gathered}
\mathrm{UI}=\text { Suma del } \% \text { de ácidos insaturados } \times \text { número } \\
\text { de enlaces dobles } .
\end{gathered}
$$

Para evaluar la calidad nutricional y lipídica de las especies de Cystoseira, se estimaron índices lipídicos (índices de aterogenicidad [IA] y de trombogenicidad [IT]) de acuerdo con el método de Ulbricht y Southgate (1991), que se basa en la composición de los AG:

$$
\begin{gathered}
\mathrm{IA}=\frac{\mathrm{C} 12: 0+4 \times \mathrm{C} 14: 0+\mathrm{C} 16: 0}{\Sigma \mathrm{MUFA}+\Sigma(\mathrm{n}-6 \text { PUFA })+\sum(\mathrm{n}-3 \text { PUFA })}, \\
\mathrm{IT}=\frac{\mathrm{C} 14: 0+\mathrm{C} 16: 0+\mathrm{C} 18: 0}{0.5 \times \Sigma \text { MUFA }+0.5 \times \sum(\mathrm{n}-6 \text { PUFA })+3 \times \Sigma(\mathrm{n}-3 \text { PUFA })+\frac{\sum(\mathrm{n}-3 \text { PUFA })}{\sum(\mathrm{n}-6 \text { PUFA })}},
\end{gathered}
$$

where MUFA indicates monounsaturated FA and PUFA indicates polyunsaturated FA.

\section{Statistical analysis}

The results were expressed as mean values \pm standard deviation of the 3 replicates. Mean total lipid and FA values were assessed using one-way analysis of variance (ANOVA) at $P<0.05$, using the Statgraphics Centurion 16.1.11 software for Windows. Multivariate analyses (Sokal and Michener donde MUFA, por sus siglas en inglés, indica ácidos grasos monoinsaturados y PUFA indica ácidos grasos polinsaturados.

\section{Análisis estadístico}

Los resultados se expresaron como los valores promedio \pm la desviación estándar de las 3 réplicas. Los valores de lípidos totales y AG fueron evaluados con un análisis de varianza (ANDEVA) de una vía a $P<0.05$, con el software Statgraphics centurion para Windows. Se llevaron a cabo 
1958) were carried out to evaluate the grouping of the studied species according to their total lipid and FA composition: (i) the cluster analysis was performed using the unweighted pair group method with arithmetic mean (UPGMA) and the Euclidean distance $\left(D_{\mathrm{E}}\right)$, the UPGMA being authentic for ecological classification tools especially in species composition (Legendre and Legendre 1998); (ii) the principal component analysis (PCA) was carried out to differentiate between species and forms. Multivariate analyses were done using the MultiVariate Statistical Package (MVSP) software for Windows v3.1, following Kovach (2007).

\section{Results}

\section{Total lipid content}

The total lipid content of the 11 Cystoseira species showed wide fluctuations (Table 1). The yield for the total lipid fraction extracted varied in the range between $1.98 \%$ (C. schiffneri) and $6.82 \% \mathrm{DW}$ (C. sauvageauana) (Table 1 ).

\section{Fatty acid profile of lipid extract}

Fourteen major FAs were identified in the lipid fraction of the 11 Cystoseira species (Table 2). The FA content of Cystoseira lipids varied widely between species. The FA profile of lipid extracts was characterized by high amounts of saturated FAs (SFAs) ranging from $40.51 \%$ (C. amentacea var. stricta) to $57.91 \%$ (C. compressa) of total FAs. Palmitic acid (C16:0) was the predominant lipid fraction, with the highest rate being found in C. foeniculacea f. tenuiramosa (44.70\%). Cystoseira barbata was found to be rich in myristic acid (C14:0, 7.45\%), while stearic acid (C18:0) characterized C. compressa (15.27\%) (Table 2).

MUFAs ranged from $25.30 \%$ of total FAs in C. compressa to $37.1 \%$ in C. schiffneri. The major MUFA ( $>20 \%$ of total FAs) for most of the studied Cystoseira species was oleic acid (C18:1).

Total PUFAs varied between $15.05 \%$ (C. compressa) and $30.35 \%$ (C. crinita). Among the PUFAs, arachidonic acid (C20:4n-6) was the most abundant in the analyzed species, with a particular high level of $15.98 \%$ in C. crinita. The highest percentage of linoleic acid (C18:2n-6) was observed in C. elegans $(7.59 \%)$, while the highest percentages of the eicosapentaenoic acid (C20:5n 3$)$ and stearidonic acid (C18:4n-3) were observed in C. crinita (3.31\%) and C. amentacea var. stricta $(3.10 \%)$, respectively. Omega 3 PUFAs were detected in all studied species. Total omega 3 ( $\left.\sum \mathrm{n}-3\right)$ ranged between $1.48 \%$ (C. elegans) and 5.69\% (C. foeniculacea f. latiramosa). Cystoseira foeniculacea f. latiramosa and $C$. crinita were the richest species in n-3 PUFA (5.69\% and 5.67\% of total FAs, respectively). This richness is associated with the high rates of n-3 marine triglyceride (C20:5n-3), an important n-3 PUFA, that they contain. Stearidonic acid (C18:4n-3) was also detected in all análisis multivariados (Sokal y Michener 1958) para evaluar el agrupamiento de las especies estudiadas de acuerdo con sus lípidos totales y composición de AG: (i) el análisis de conglomerados se realizó utilizando el método de agrupación de pares no ponderados con la media aritmética (UPGMA, por sus siglas en inglés) y la distancia euclidiana $\left(D_{\mathrm{E}}\right)$, de los cuales el UPGMA es aceptado como una herramienta útil para la clasificación ecológica, especialmente en la composición de especies (Legendre y Legendre 1998); (ii) el análisis de componentes principales (ACP) fue realizado para diferenciar entre especies y formas. Se usó el software Multi-Variate Statistical Package (MVSP) para Windows v3.1 de acuerdo con Kovach (2007).

\section{Resultados}

\section{Contenido de lípidos totales}

El contenido de lípidos totales de las 11 especies de Cystoseira mostró fluctuaciones amplias (Tabla 1). El contenido de la fracción lipídica total extraída varió en un rango de $1.98 \%$ (C. schiffneri) a $6.82 \%$ del PS (C. sauvageauana) (Tabla 1).

\section{Perfil de ácidos grasos de los extractos de lípidos}

Se identificaron 14 AG mayoritarios en la fracción lipídica de las 11 especies de Cystoseira (Tabla 2). El contenido de AG de los lípidos de Cystoseira varió mucho entre las especies. El perfil de los AG de los lípidos extraídos se caracterizó por altas cantidades de ácidos grasos saturados (AGS) que variaron entre $40.51 \%$ (C. amentacea var. stricta) y $57.91 \%$ (C. compressa) de los AG totales. El ácido palmítico (C16:0) fue la fracción lipídica predominante, con la tasa más alta encontrada en $C$. foeniculacea $\mathrm{f}$. tenuiramosa $(44.70 \%)$. Se encontró que el ácido mirístico (C14:0) abundó en $C$. barbata (7.45\%), mientras que el ácido esteárico $(\mathrm{C} 18: 0)$ caracterizó a C. compressa (15.27\%) (Tabla 2).

Los MUFA variaron de $25.30 \%$ de los AG totales en C. compressa a $37.1 \%$ en C. schiffneri. El ácido oleico (C18:1) fue el MUFA principal (>20\% de los AG totales) para la mayoría de las especies de Cystoseira estudiadas.

Los PUFA variaron entre $15.05 \%$ (C. compressa) y $30.35 \%$ (C. crinita). Entre los PUFA, el ácido araquidónico (C20:4n-6) fue el más abundante en las especies analizadas, con un nivel particularmente alto de $15.98 \%$ en C. crinita. El porcentaje más alto de ácido linoleico (C18:2n-6) se observó en C. elegans (7.59\%), mientras que los porcentajes más altos de ácido eicosapentaenoico (C20:5n-3) y ácido estearidónico (C18:4n-3) se observaron en C. crinita (3.31\%) y C. amentacea var. stricta (3.10\%), respectivamente. Los PUFA omega 3 se detectaron en todas las especies estudiadas. Los omega 3 totales $\left(\sum \mathrm{n}-3\right)$ variaron entre $1.48 \%$ (C. elegans) y $5.69 \%$ (C. foeniculacea $\mathrm{f}$. latiramosa). Cystoseira foeniculacea f. latiramosa y C. crinita fueron las especies con mayor riqueza de PUFA n-3 (5.69\% 
Table 1. Lipid extracts of Cystoseira species collected along the Tunisian coast. DW, dry weight; FW, fresh weight; N, northern coast of Tunisia; and S, southeastern coast of Tunisia. Tabla 1. Extractos lipídicos de los taxones de Cystoseira recolectados a lo largo de la costa tunecina. DW, peso seco; FW, peso fresco; N, costa norte de Túnez; y S, costa sureste de Túnez.

\begin{tabular}{|c|c|c|}
\hline \multirow[t]{2}{*}{ Species } & \multicolumn{2}{|c|}{ Total lipids } \\
\hline & $\left(\mathrm{mg} \cdot \mathrm{g}^{-1} \mathrm{DW}\right)^{*}$ & Yield* (FW\% w/w) \\
\hline Cystoseira amentacea var. stricta $(\mathrm{N})$ & $39.60 \pm 3.60^{\mathrm{cd}}$ & $5.28 \pm 2.31^{\mathrm{cd}}$ \\
\hline Cystoseira barbata $(\mathrm{S})$ & $30.80 \pm 2.80^{\text {ef }}$ & $4.11 \pm 1.80^{\text {ef }}$ \\
\hline Cystoseira compressa $(\mathrm{N})$ & $46.20 \pm 4.20^{\mathrm{bc}}$ & $6.16 \pm 2.70^{\mathrm{bc}}$ \\
\hline Cystoseira crinita $(\mathrm{N})$ & $66.00 \pm 6.00^{\mathrm{a}}$ & $8.80 \pm 3.86^{\mathrm{a}}$ \\
\hline Cystoseira elegans (S) & $47.50 \pm 4.50^{\mathrm{b}}$ & $6.33 \pm 2.78^{b}$ \\
\hline Cystoseira foeniculacea $(\mathrm{N})$ & $52.80 \pm 4.80^{\mathrm{b}}$ & $7.04 \pm 3.09^{\mathrm{b}}$ \\
\hline Cystoseira foeniculacea f. latiramosa $(\mathrm{N})$ & $24.20 \pm 2.20^{\mathrm{fg}}$ & $3.23 \pm 1.41^{\mathrm{fg}}$ \\
\hline Cystoseira foeniculacea $\mathrm{f}$. tenuiramosa $(\mathrm{N})$ & $31.20 \pm 2.40^{\mathrm{e}}$ & $4.16 \pm 1.82^{\mathrm{e}}$ \\
\hline Cystoseira foeniculacea f. tenuiramosa (S) & $33.00 \pm 3.00^{\mathrm{de}}$ & $4.40 \pm 1.93^{\mathrm{de}}$ \\
\hline Cystoseira sauvageauana $(\mathrm{N})$ & $68.20 \pm 6.20^{\mathrm{a}}$ & $9.09 \pm 3.99^{\mathrm{a}}$ \\
\hline Cystoseira schiffneri $(\mathrm{S})$ & $19.80 \pm 1.80^{\mathrm{g}}$ & $2.64 \pm 1.16^{\mathrm{g}}$ \\
\hline Cystoseira sedoides $(\mathrm{N})$ & $33.00 \pm 3.00^{\text {de }}$ & $4.40 \pm 1.93^{\mathrm{de}}$ \\
\hline
\end{tabular}

*Data are expressed as mean $\pm \mathrm{SD}$, where $n=3$; values in a column without a common superscript are significantly different $(P<0.05)$.

studied species in rates varying between $0.62 \%$ (C. elegans) and $3.10 \%(C$. amentacea var. stricta). Linoleic acid $(\mathrm{C} 18: 2 \mathrm{n}-6)$ was found in all studied species at rates ranging between $2.42 \%$ (C. sedoides) and $7.59 \%$ (C. elegans). Cystoseira crinita was the richest in the dihomo- $\gamma$-linolenic acid (C20:3n-6, 2.07\%), an uncommon FA.

\section{Discrimination of Cystoseira}

The results of FA composition were evaluated using multivariate analyses to investigate whether the various lipid and FA patterns correlated with the taxonomic position of the brown Cystoseira algae and lead to distinguish between species and forms. Differentiating species according to their chemical composition could be valuable when examining any possible relationship between them. In this regard, a PCA was performed to consider the FA composition of each sample investigated. The 3 axes accounted for $86.89 \%$ of total variance. The first 2 dimensions explained $78.07 \%$ of the variability. Principal component (PC) 1 was defined by palmitic acid (C16:0), oleic acid (C18:1n-9), and arachidonic acid (C20:4n-6), while the most discriminant variable along the $\mathrm{PC} 2$ axis was stearic acid (C18:0) and explained $27.89 \%$ of total variation. PC3 was defined by elaidic acid (Trans C18:1), myristic acid (C14:0), palmitoleic acid (C16:1n-7), and linoleic acid (C18:2n-6). Plotting on axes 1 and 2 divided species into 3 major groups (Fig. 3). The first group included only y $5.67 \%$ del total de los AG, respectivamente). Esta riqueza se relaciona con las altas tasas de triglicérido $n-3$ de origen marino (C20:5n-3), un PUFA n-3 importante, que contienen estas especies. El ácido estearidónico (C18:4n-3) también se detectó en todas las especies estudiadas; este varió entre $0.62 \%$ (C. elegans) y $3.10 \%$ (C. amentacea var. stricta). El ácido linoleico (C18:2n-6) se encontró en todas las especies estudiadas en cantidades que variaron entre $2.42 \%$ (C. sedoides) y $7.59 \%$ (C. elegans). Cystoseira crinita presentó la mayor cantidad de ácido dihomo- $\gamma$-linolénico (C20:3n-6; 2.07\%), un AG poco común.

\section{Discriminación de Cystoseira}

Los resultados de la composición de AG se evaluaron con análisis multivariados para investigar si los diversos patrones de los lípidos y los AG se correlacionaban con la posición taxonómica de las algas pardas de Cystoseira y permitirían la distinción entre especies y formas. La diferenciación de especies por su composición química podría ser valiosa cuando se examina cualquier relación posible entre ellas. Por lo tanto, se llevó a cabo un ACP para considerar la composición de los AG de cada muestra investigada. Los 3 ejes explicaron el $86.89 \%$ de la varianza total. Las primeras 2 dimensiones explicaron el $78.07 \%$ de la variabilidad. El componente principal (CP) 1 se definió por el ácido palmítico (C16:0), ácido oleico (C18:1n-9) y ácido araquidónico (C20:4n-6), mientras que la variable que más discriminó en el eje del CP2 fue el 


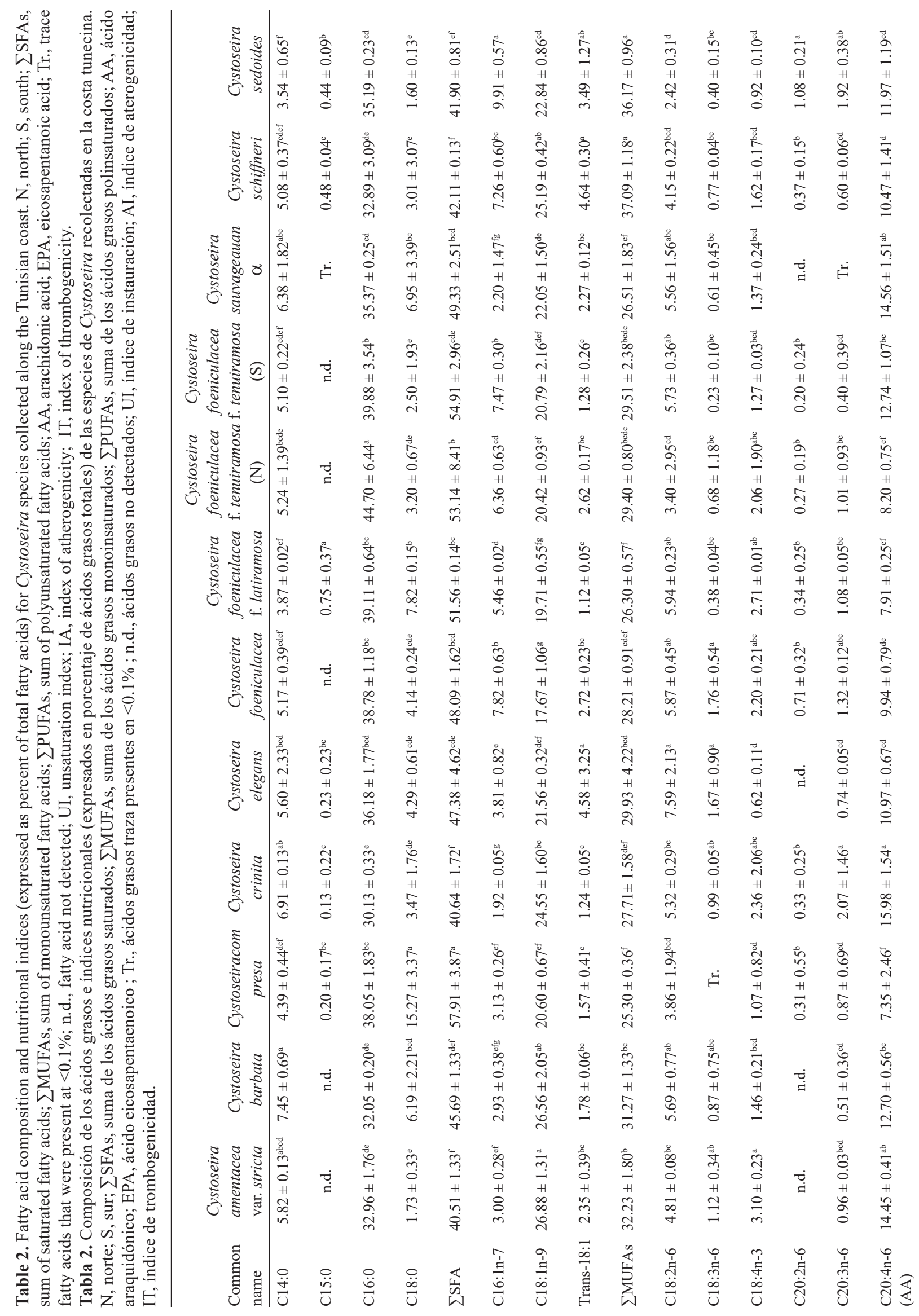


Bouafif et al.: Fatty acid profile of Tunisian Cystoseira species

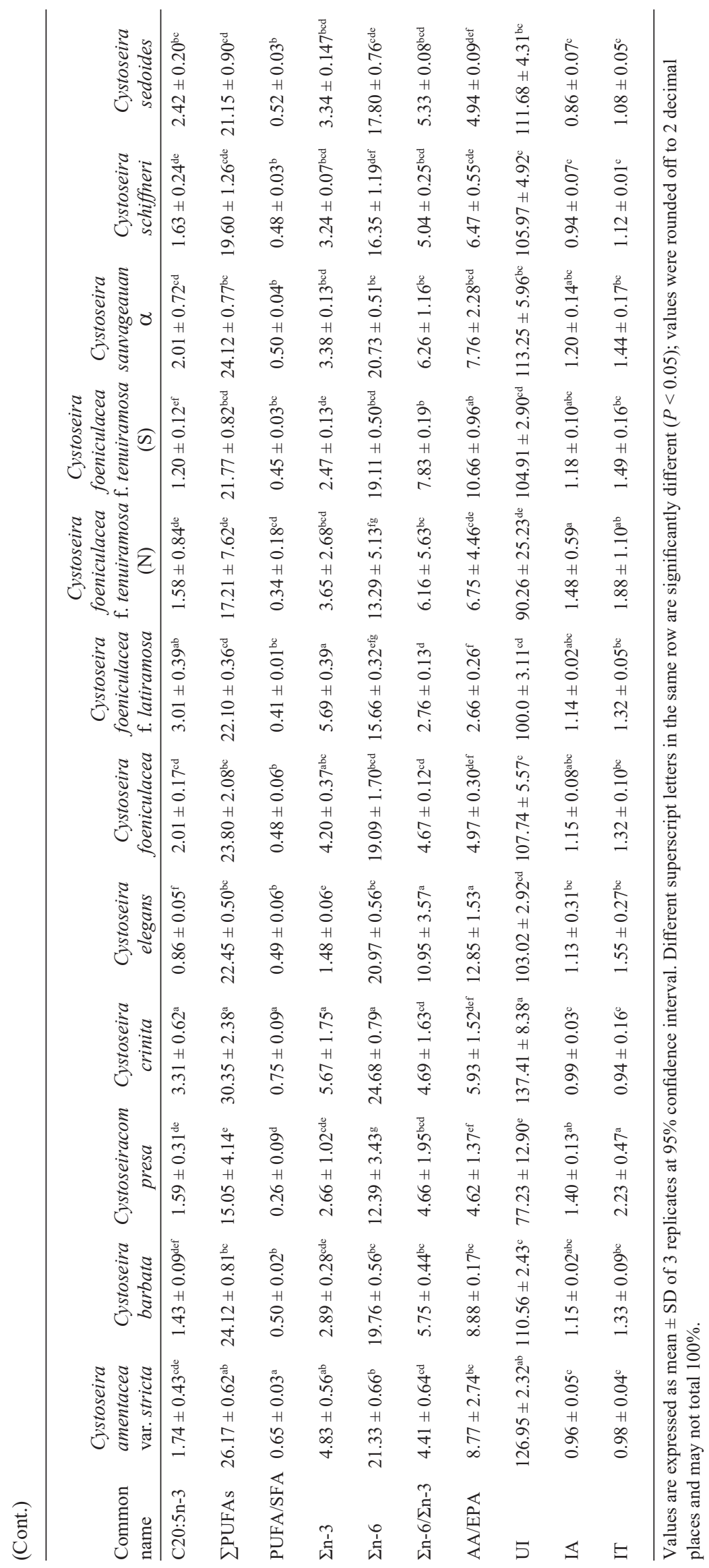


C. compressa, the second comprised the $C$. foeniculacea group $(C$. foeniculacea and its forms tenuiramosa and latiramosa), and the third, the most heterogeneous one, comprised the other Cystoseira samples (Fig. 3).

With the hierarchical clustering analysis, the dendrogram of FAs for the Cystoseira samples showed the presence of 4 clusters that were connected at $D_{E}=14.7$ (Fig. 4). Species were grouped independently of their geographic distribution. The greatest similarity was observed between $C$. amentacea var. stricta and C. crinita at $D_{E}=5.2$. As in the PCA model, the C. foeniculacea forms were closely linked and grouped in a single cluster at $D_{E}=11.4$ (Fig. 4 ).

\section{Nutritional quality assessment}

The PUFA/SFA ratio is commonly used to evaluate the nutritional quality of the lipid fraction of foods. Except for $C$. compressa and $C$. foeniculacea $\mathrm{f}$. tenuiramosa, the Cystoseira species analyzed in the present study exhibited PUFA/SFA ratios exceeding 0.4 (Table 2). The n-3 and n-6 PUFAs represent a significant part of the Cystoseira lipids. The n-3 PUFA ranged between $1.48 \%$ (C. elegans) and 5.69\% (C. foeniculacea f. latiramosa), while the n-6 PUFA varied between $12.39 \%$ (C. compressa) and $24.68 \%$ (C. crinita) of total FA. The 11 Cystoseira species exhibited high unsaturation indices, varying from 77.23 (C. compressa) to 137.41 (C. crinita). The highest IA and IT values were, respectively, 1.48 (C. foeniculacea f. tenuiramosa) and 2.23 (C. compressa) (Table 2).

\section{Discussion}

Total lipid content in the 11 Cystoseira species analyzed in this study was close to that reported for C. brachycarpa (Ragonese et al. 2014) off Italy and C. osmundacea (Khotimchenko et al. 2002) in the Sea of Japan. However, total lipid rates for Tunisian Cystoseira were higher than those for Moroccan Cystoseira from the Atlantic (between 1.3 and $16 \mathrm{mg} \cdot \mathrm{g}^{-1} \mathrm{DW}$, Valls et al. 1993) and those for Indian Cystoseira (between 6.1 and $6.7 \mathrm{mg} \cdot \mathrm{g}^{-1}$ fresh weight [FW], Kumari et al. 2013). The species investigated here are poorly studied in the world as regards their total lipid content. This study shows that Tunisian C. barbata $\left(4.11 \mathrm{~g} \cdot 100 \mathrm{~g}^{-1} \mathrm{FW}\right)$ and C. crinita $\left(8.8 \mathrm{~g} \cdot 100 \mathrm{~g}^{-1} \mathrm{FW}\right)$ are richer in total lipids than species from the Black Sea harvested during the same season $\left(0.84 \mathrm{~g} \cdot 100 \mathrm{~g}^{-1} \mathrm{FW}\right.$ for C. barbata [Ivanova et al. 2012] and $0.72 \mathrm{~g} \cdot 100 \mathrm{~g} \mathrm{~g}^{-1} \mathrm{FW}$ for C. crinita [Ivanova et al. 2013]), and these differences are related to environmental conditions. In fact, it is proven that in algae, total lipid content depends on temperature, light, and salinity (Kim et al. 1996), factors that are very different between Tunisian and Black Sea waters. Intraspecific variability in total lipid content could also be dependent on the physiological state of the species, as suggested by the higher rate observed in this study for C. barbata (3.08\%), compared to that reported by Frikha et al. (2011) for ácido esteárico (C18:0), el cual explicó el 27.89\% de la variación total. El CP3 se definió por ácido elaídico (Trans C18:1), ácido mirístico (C14:0), ácido palmitoleico (C16:1n-7) y ácido linoleico (C18:2n-6). El trazo sobre los ejes 1 y 2 dividió las especies en 3 grupos principales (Fig. 3). El primer grupo se formó únicamente por $C$. compressa, el segundo incluyó al grupo $C$. foeniculacea ( $C$. foeniculacea y sus formas tenuiramosa y latiramosa) y el tercero, el más heterogéneo, incluyó las otras muestras de Cystoseira (Fig. 3).

En el análisis de agrupamiento jerárquico, el dendrograma de los AG de las muestras de Cystoseira presentó 4 conglomerados que estaban conectados a una $D_{E}=14.7$ (Fig. 4). Las especies se agruparon independientemente de sus distribuciones geográficas. La mayor similitud se observó entre C. amentacea var. stricta y C. crinita a $D_{E}=5.2$. Así como en el modelo del ACP, las formas de C. foeniculacea estuvieron conectadas de manera cercana y agrupadas en un único conglomerado a $D_{E}=11.4$ (Fig. 4).

\section{Evaluación de la calidad nutricional}

La relación de PUFA/AGS comúnmente se usa para evaluar la calidad nutricional de la fracción lipídica de los alimentos. Con la excepción de $C$. compressa y $C$. foeniculacea $\mathrm{f}$. tenuiramosa, las especies de Cystoseira que se investigaron en el presente estudio presentaron relaciones de PUFA/AGS mayores que 0.4 (Tabla 2). Los PUFA n-3 y n-6 representaron una parte significativa de los lípidos de Cystoseira. Los PUFA n-3 variaron entre $1.48 \%$ (C. elegans) y $5.69 \%$ (C. foeniculacea f. latiramosa), mientras que los PUFA n-6 variaron entre $12.39 \%$ (C. compressa) y $24.68 \%$ (C. crinita) del total de los AG. Las 11 especies de Cystoseira estudiadas presentaron índices de instauración altos que variaron de 77.23 (C. compressa) a 137.41 (C. crinita). Los valores más altos del IA y el IT fueron 1.48 (C. foeniculacea $\mathrm{f}$. tenuiramosa) y 2.23 (C. compressa), respectivamente (Tabla 2).

\section{Discusión}

El contenido de los lípidos totales de las 11 especies de Cystoseira investigadas en el presente estudio fue cercano al reportado para la C. brachycarpa de Italia (Ragonese et al. 2014) y para la C. osmundacea del mar de Japón (Khotimchenko et al. 2002). Sin embargo, las tasas de los lípidos totales de las especies de Cystoseira de Túnez fueron más altas que las de las especies de Cystoseira de Marruecos del océano Atlántico (entre $1.3 \mathrm{y} 16 \mathrm{mg} \cdot \mathrm{g}^{-1} \mathrm{PS}$, Valls et al. 1993) y las de las especies de Cystoseira de la India (entre 6.1 y $6.7 \mathrm{mg} \cdot \mathrm{g}^{-1}$ peso fresco [PF], Kumari et al. 2013). En el mundo, hay pocos estudios de los lípidos totales de las especies aquí estudiadas. Este estudio demuestra que C. barbata $\left(4.11 \mathrm{~g} \cdot 100 \mathrm{~g}^{-1} \mathrm{PF}\right)$ y C. crinita $\left(8.8 \mathrm{~g} \cdot 100 \mathrm{~g}^{-1} \mathrm{PF}\right)$ de Túnez son más ricas en lípidos totales que las especies del mar Negro que se recolectaron durante la misma estación $\left(0.84 \mathrm{~g} \cdot 100 \mathrm{~g}^{-1} \mathrm{PF}\right.$ para C. barbata [Ivanova et al. 2012] y $0.72 \mathrm{~g} \cdot 100 \mathrm{~g}^{-1} \mathrm{PF}$ para 


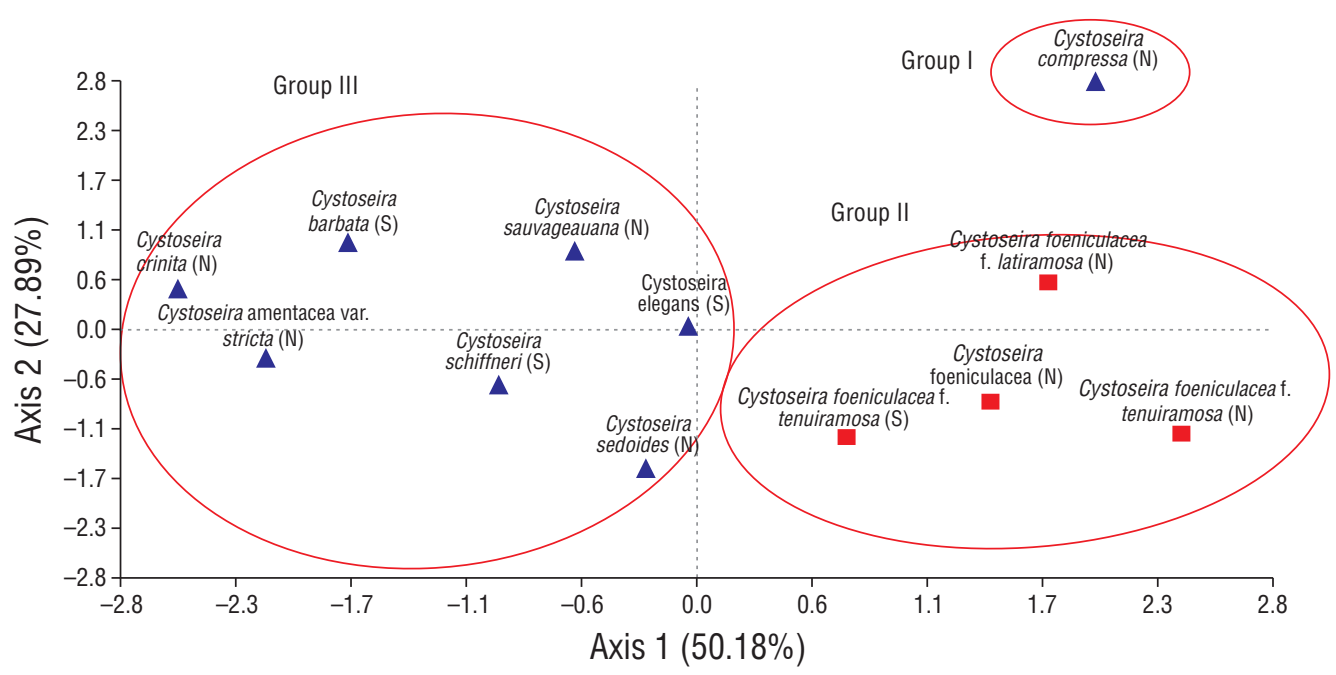

Figure 3. Principal component analysis using fatty acid composition of Cystoseira taxa. The Cystoseira foeniculacea forms are denoted by squares. S, south; and N, north.

Figura 3. Análisis de componentes principales usando la composición de los ácidos grasos de los taxones de Cystoseira. Las formas de Cystoseira foeniculacea están señaladas con cuadros; S, sur; y N, norte.

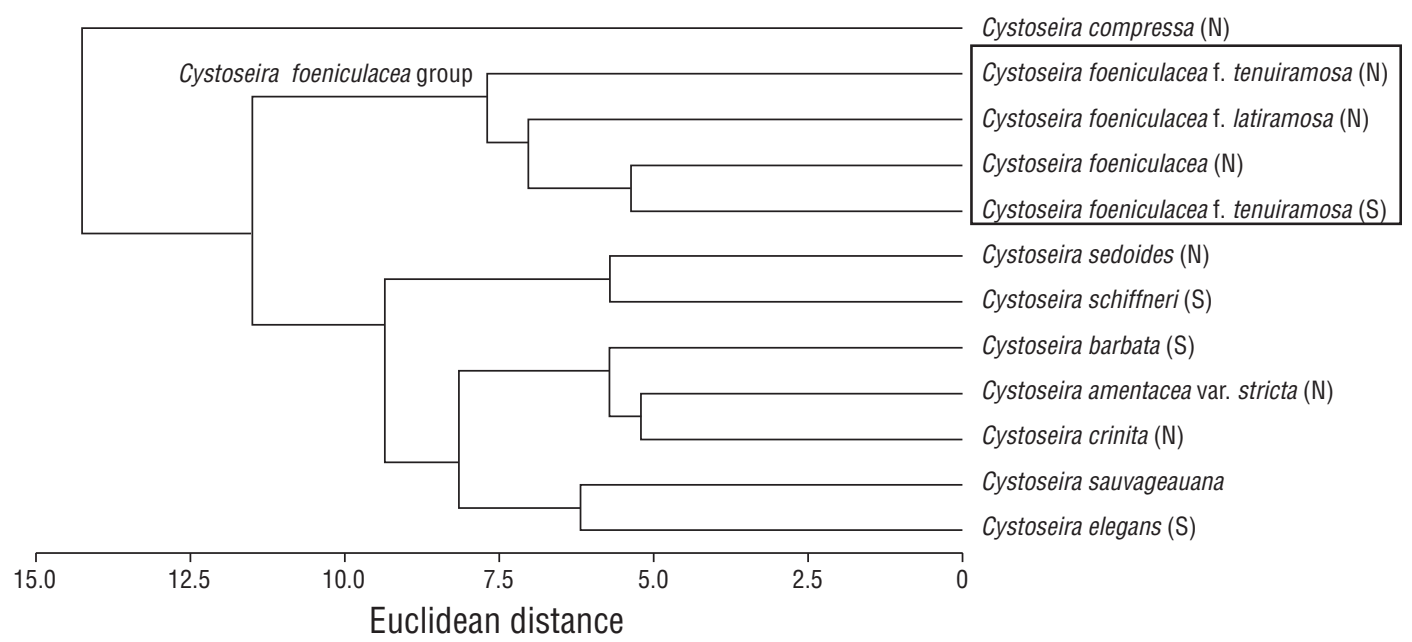

Figure 4. Dendrogram showing hierarchical clustering (UPGMA method) of Cystoseira samples by fatty acid content. S, south; N, north.

Figura 4. Dendrograma que muestra el agrupamiento jerárquico (método UPGMA) de las muestras de Cystoseira por contenido de ácidos grasos. S, sur; N, norte.

the same species in almost the same environmental conditions ( $2.51 \%$, Gulf of Gabès, Tunisian southern coast).

In General, C. compressa was the richest in SFA, whereas C. amentacea var. stricta and C. schiffneri stood out for their high content of PUFA and MUFA. Palmitic acid (C16:0) was the main FA of the Cystoseira lipids, followed by oleic acid. These results confirm data previously reported in the literature for the profile commonly seen in brown algae, especially in Cystoseira species (Khotimchenko et al. 2002; Ivanova et al. 2012, 2013; Kumari et al. 2013; Ragonese et al. 2014; Vizetto-Duarte et al. 2015). For a given taxon, the differences between the FA profile observed in Tunisia and
C. crinita [Ivanova et al. 2013]), y estas diferencias se deben a las condiciones ambientales. De hecho, está confirmado que el contenido de lípidos totales en las algas depende de la temperatura, la luz y la salinidad (Kim et al. 1996), factores que difieren mucho entre las aguas de Túnez y el mar Negro. La variabilidad intraespecífica en el contenido de lípidos totales también puede depender del estado fisiológico de las especies, como lo sugiere la tasa observada en este estudio para C. barbata (3.08\%), la cual es más alta que la reportada por Frikha et al. (2011) para la misma especie bajo condiciones ambientales muy similares $(2.51 \%$, golfo de Gabés, costa sur de Túnez). 
those reported in the literature for other regions could be related to the different seasons in which the studied samples were harvested and so to the different physiological states of the concerned species and/or to the differences in environmental conditions of habitats in the different regions. Temperature seems to be the factor that most affects the percentage of SFA and PUFA; for instance, Colombo et al. (2006) proved that algae from cold water (e.g., Canada) were usually richer in PUFA, with a higher n-3/n-6 FA ratio, than algae from warm water (e.g., China), and studies carried out in cold waters (Atlantic waters) exhibited higher SFA ratios than PUFA ratios in Cystoseira species (Vizetto-Duarte et al. 2015). However, the highest PUFA ratios found in warm-water algae from the Sea of Japan (Nomura et al. 2013) suggest that the environmental factors in the species' habitat, other than temperature, could influence the FA profiles of algae.

Species from different localities did not show clustering behavior along the 2 axes of the PCA (Fig. 3). Furthermore, the PCA score plot of species highlighted that the FA composition of a species was independent of its origin. This low geographic differentiation could be explained by intraspecific diversity, which might affect the variability in FA composition. Samples of the C. foeniculacea group were distributed mainly along axis 2 and aggregated close to each other (group 2), showing low variation in the pool of variables considered and that species displayed a similar lipid profile (Fig. 3). The C. foeniculacea group was clustered according to its forms. Cystoseira foeniculacea $\mathrm{f}$. tenuiramosa from different regions (north and south) were grouped together.

It is not surprising that $C$. schiffneri was segregated from the $C$. foeniculacea group since $C$. schiffneri (sensu Hamel 1939) (Hamel 1931-1939), considered as a synonym of C. foeniculacea f. schiffneri (Hamel) Gómez-Garreta, Barceló, Ribera and Rull Lluch (Gómez-Garreta et al. 2001), was recently reinstated as a specific rank, a distinct entity of the Cystoseira species (Bouafif et al. 2016). This discrimination of Cystoseira based on FAs supports the reinstatement of C. schiffneri (Hamel) as a specific rank.

Hierarchical clustering analysis revealed that species were more related to each other by their FA composition than by their geographic distribution, highlighting the intraspecific diversity in the genus Cystoseira (Fig. 4). The clustering of the $C$. foeniculacea group according to the FA profile supports earlier evidence that lipid composition could be a biochemical marker for each taxonomic group.

The PUFA/SFA ratios obtained in the present study are within the nutritional guidelines recommending a PUFA/SFA ratio higher than 0.4 (Wood et al. 2004). The n-6/n-3 PUFA ratios ranging from 2.76 (C. foeniculacea $\mathrm{f}$. latiramosa) to 10.95 (C. elegans) for the 11 Cystoseira species were comparable to those for Portuguese Cystoseira species (Vizetto-Duarte et al. 2015), and these high ratios
En general, C. compressa fue la más rica en AGS, mientras que C. amentacea var. stricta y $C$. schiffneri sobresalieron por sus altos contenidos de PUFA y MUFA. El ácido palmítico (C16:0) fue el AG mayoritario de los lípidos de Cystoseira, seguido por el ácido oleico. Estos resultados confirman los datos reportados previamente en la literatura para los perfiles observados comúnmente en las algas pardas, especialmente en las especies de Cystoseira (Khotimchenko et al. 2002; Ivanova et al. 2012, 2013; Kumari et al. 2013; Ragonese et al. 2014; Vizetto-Duarte et al. 2015). Para un taxón dado, las diferencias entre los perfiles de AG observados en Túnez y los reportados en la literatura para otras regiones podrían relacionarse a las diferentes estaciones en las que se recolectaron las muestras estudiadas y, por lo tanto, a los diferentes estados fisiológicos de las especies en cuestión y/o a las diferentes condiciones ambientales de los hábitats en las diferentes regiones. La temperatura parece ser el factor que más afecta el porcentaje de AGS y PUFA; por ejemplo, Colombo et al. (2006) comprobó que las algas de aguas frías (e.g., Canadá) eran generalmente más ricas en PUFA, con una mayor proporción de $A G$ n-3/n-6, que las algas de aguas cálidas (e.g., China), y los estudios realizados en aguas frías (Atlántico) mostraron mayores proporciones de AGS que de PUFA en las especies de Cystoseira (Vizetto-Duarte et al. 2015). Sin embargo, las proporciones más altas de PUFA encontradas en las algas de las aguas cálidas del mar de Japón (Nomura et al. 2013) sugieren que los factores ambientales de los hábitats de las especies, además de la temperatura, podrían influenciar los perfiles de AG de las algas.

Las especies de diferentes localidades no demostraron un comportamiento de agrupamiento a lo largo de los 2 ejes del ACP (Fig. 3). Además, la gráfica del ACP de las especies destacó que la composición de los AG de una especie era independiente de su origen. La baja diferenciación geográfica se podría explicar por la diversidad intraespecífica, que podría afectar la variabilidad de la composición de los AG. Las muestras del grupo C. foeniculacea se distribuyeron principalmente a lo largo del eje 2 y se agruparon de manera cercana (grupo 2), lo que demostró que la variación en el grupo de variables consideradas fue baja y que el perfil lipídico presentado por las especies fue similar (Fig. 3). El grupo C. foeniculacea se agrupó por sus formas. Cystoseira foeniculacea f. tenuiramosa provenientes de diferentes regiones (norte y sur) se agruparon juntas.

No es sorprendente que C. schiffneri se segregó del grupo C. foeniculacea ya que C. schiffneri (sensu Hamel, 1939) (Hamel 1931-1939), previamente considerada un sinónimo de C. foeniculacea f. schiffneri (Hamel) Gómez-Garreta, Barceló, Ribera y Rull Lluch (Gómez-Garreta et al. 2001), fue restablecida recientemente a categoría de especie, una entidad distintiva de las especies de Cystoseira (Bouafif et al. 2016). La discriminación de Cystoseira basada en AG apoya la restitución de C. schiffneri (Hamel) a categoría de especie. 
are explained by the high levels of n-6 PUFAs in the lipid composition of the species. Seaweed FAs are beneficial for the prevention of cardiovascular diseases and other chronic diseases, such as diabetes, hypertension, and autoimmune disease, in humans (Dawczynski et al. 2007). Some studies suggested a beneficial n-6/n-3 ratio between 1:1 and 5:1 for human nutrition (Simopoulos 2002, 2008); the Food and Agriculture Organization of the United Nations/World Health Organization committee recommended, in turn, an n-6/n-3 ratio between 5:1 and 10:1 (FAO/WHO 1995). Regarding our results, all 11 Tunisian Cystoseira species have high nutritional values.

High IA and IT values have adverse effects on human health and are considered potent indicators of and important factors for increased risk of coronary heart disease, where the higher the values the more degraded the nutritional quality (Ulbricht and Southgate 1991). The IT values for the algae analyzed in the present study were comparable to the IT values found by Ulbricht and Southgate (1991) for meat (0.7-1.1) and milk-based products (1.32). Thus, the results obtained in the present study suggest that $C$. amentacea, $C$. crinita, and C. sedoides were more antithrombogenic and antiatherogenic than the other analyzed Cystoseira species and could be used in nutraceuticals or food.

In conclusion, all studied species of Cystoseira have the same qualitative major FA composition. Interspecific quantitative variability in FA composition is, however, pointed out. This variability could be linked to environmental, biological, and physiological factors. Clustering of C. foeniculacea and its infrataxa (the latiramosa and tenuiramosa forms) according to the FA profiles suggest a possible use of FA composition for taxonomic purposes for the genus Cystoseira. This study further supports and confirms the recent study by Bouafif et al. (2016) about the reinstatement of the endemic Mediterranean C. schiffneri, considered before as a form of $C$. foeniculacea. The PUFA/SFA, n-6/n-3 PUFA, IA, and IT, indicators of nutritional lipid quality in food, suggest that the Cystoseira species studied here can be an interesting source of dietary FAs with beneficial effects on human health.

To our knowledge, this work is one of the rare investigations of lipid composition and nutritional value of Mediterranean Cystoseira species, some of which are rare and endemic.

\section{ACKNOWLEDGMENTS}

We are grateful to the Regional Activity Center for Specially Protected Areas for its financial support. The authors are grateful to the staff from the Laboratory of Plant Biotechnology (National Institute of Applied Science and Technology, Tunis, Tunisia) for their technical assistance. Many thanks go to the anonymous reviewers for their comments and constructive criticism of the manuscript.
El análisis de agrupamiento jerárquico demostró que las especies se relacionaron más por su composición de AG que por su distribución geográfica, destacando la diversidad intraespecífica en el género Cystoseira (Fig. 4). El agrupamiento del grupo $C$. foeniculacea de acuerdo con el perfil de AG apoya la evidencia previa de que la composición lipídica podría ser un marcador bioquímico para cada grupo taxonómico.

Las proporciones de PUFA/AGS obtenidas en el presente estudio se encuentran dentro de las normas nutricionales que recomiendan una proporción de PUFA/AGS mayor que 0.4 (Wood et al. 2004). Las proporciones de PUFA n-6/n-3 que variaron de 2.76 (C. foeniculacea $\mathrm{f}$. latiramosa) a 10.95 (C. elegans) para las 11 especies de Cystoseira investigadas en el presente estudio fueron comparables con las de las especies de Cystoseira de Portugal (Vizetto-Duarte et al. 2015), y estas proporciones elevadas se explican por los altos niveles de PUFA n-6 en la composición lipídica de las especies. Los AG de las macroalgas son benéficos para la prevención de enfermedades cardiovasculares y otras enfermedades crónicas, como diabetes, hipertensión y enfermedades autoinmunes en humanos (Dawczynski et al. 2007). Algunos estudios sugieren que la proporción de n-6/n-3 que es benéfica para la nutrición humana es de entre 1:1 y 5:1 (Simopoulos 2002, 2008); a su vez, el comité de la Organización de las Naciones Unidas para la Alimentación y la Agricultura y la Organización Mundial de la Salud recomendó una proporción de n-6/n-3 de entre 5:1 y 10:1 (FAO/WHO 1995). De acuerdo con nuestros resultados, las 11 especies de Cystoseira de Túnez estudiadas presentan altos valores nutricionales.

Altos valores del IA y del IT tienen efectos adversos en la salud humana y son considerados indicadores potentes de y factores importantes en el incremento del riesgo de desarrollar enfermedades de las arterias coronarias; entre mayor sea el valor mayor es la degradación de la calidad nutricional (Ulbricht y Southgate 1991). Los valores del IT para las algas estudiadas en el presente estudio fueron comparables con los valores del IT encontrados por Ulbricht y Southgate (1991) para carne (0.7-1.1) y productos lácteos (1.32). Por lo tanto, los resultados obtenidos en el presente estudio sugieren que $C$. amentacea, $C$. crinita y $C$. sedoides son más antitrombogénicas y antiaterogénicas que las otras especies de Cystoseira investigadas y podrían usarse en nutracéuticos o alimentos.

En conclusión, todas las especies de Cystoseira tienen la misma composición cualitativa de AG mayoritarios. Sin embargo, se destaca la variabilidad cuantitativa interespecifica en la composición de AG. Esta variabilidad podría estar relacionada con factores ambientales, biológicos y fisiológicos. El agrupamiento de C. foeniculacea y sus infrataxones (formas latiramosa y tenuiramosa) por los perfiles de AG sugiere que la composición de AG puede usarse con propósitos taxonómicos para el género Cystoseira. Este estudio respalda y confirma el estudio reciente de Bouafif et al. (2016) sobre la restitución a la categoría de especie de C. schiffneri, especie endémica del Mediterráneo 


\section{REFERENCES}

Abdala-Díaz RT, Cabello-Pasini A, Márquez-Garrido E, LópezFigueroa F. 2014. Intra-thallus variation of phenolic compounds, antioxidant activity, and phenolsulphatase activity in Cystoseira tamariscifolia (Phaeophyceae) from southern Spain = Variación intratalo de compuestos fenólicos, actividad antioxidante y actividad de la fenolsulfatasa en Cystoseira tamariscifolia (Phaeophyceae) del sur de España. Cienc. Mar. 40(1): 1-10. http://dx.doi.org/10.7773/cm.v40i1.2350

Amico V. 1995. Marine brown algae of family Cystoseiraceae: Chemistry and chemotaxonomy. Phytochemistry 39(6): 12571279. https://doi.org/10.1016/0031-9422(95)00199-h

Barre SLL, Weinberger F, Kervarec N, Potin P. 2004. Monitoring defensive responses in macroalgae- limitations and perspectives. Phytochem. Rev. 3(3): 371-379. https://doi.org/10.1007/s11101-005-1459-3

Bouafif C, Verlaque M, Langar H. 2014. Cystoseira taxa new for the marine flora of Tunisia. Cryptogamie Algol. 35(3): 269283.

http://dx.doi.org/10.7872/crya.v35.iss3.2014.269

Bouafif C, Verlaque M, Langar H. 2016. New contribution to the knowledge of the genus Cystoseira C. Agardh in the Mediterranean Sea, with the reinstatement of species rank for C. schiffneri Hamel. Cryptogamie Algol. 37(2): 133-154. http://dx.doi.org/10.7872/crya/v37.iss2.2016.133

Calder PC. 2006. n-3 polyunsaturated fatty acids, inflammation, and inflammatory diseases. Am. J. Clin. Nutr. 83(6): $1505 \mathrm{~S}-1519 \mathrm{~S}$. https://doi.org/10.1093/ajen/83.6.1505S

Colombo ML, Risè P, Giavarini F, De Angelis L, Galli C, Bolis CL. 2006. Marine macroalgae as sources of polyunsaturated fatty acids. Plant Foods Hum. Nutr. 61(2): 64-69. https://doi.org/10.1007/s11130-006-0015-7

Connan S, Deslandes E, Gall EA. 2007. Influence of day-night and tidal cycles on phenol content and antioxidant capacity in three temperate intertidal brown seaweeds. J. Exp. Mar. Biol. Ecol. 349(2): 359-369. https://doi.org/10.1016/j.jembe.2007.05.028

Dawczynski C, Schubert R, Jahreis G. 2007. Amino acids, fatty acids, and dietary fibre in edible seaweed products. Food Chem. 103(3): 891-899.

https://doi.org/10.1016/j.foodchem.2006.09.041

Ercegovič A. 1952. Fauna i Flora Jadrana. Jadranske cistozire. Njihova morfologija, ekologija i razvitak/Fauna et Flora Adriatica. Vol. 2- Split, Institut za Oceanografiju i Ribarstvo Split, pp. 1-172 (Croatian), 173-210 (French), 211-212 (references), Map.

[FAO/WHO] Food and Agriculture Organization of the United Nations/World Health Organization. 1995. WHO and FAO joint consultation: Fats and oils in human nutrition. Nutr. Rev. 53(7): 202-205. https://doi.org/10.1111/j.1753-4887.1995.tb01552.x

Frikha F, Kammoun M, Hammami N, Mchirgui RA, Belbahri L, Gargouri Y, Miled N, Ben-Rebah F. 2011. Chemical composition and some biological activities of marine algae collected in Tunisia $=$ Composición química $\mathrm{y}$ algunas actividades biológicas de algas marinas recolectadas en Túnez. Cienc. Mar. 37(2): 113-124.

https://doi.org/10.7773/cm.v37i2.1712

Galloway AWE, Britton-Simmons KH, Duggins DO, Gabrielson PW, Brett MT. 2012. Fatty acid signatures differentiate marine macrophytes at ordinal and family ranks. J. Phycol. 48(4): 956-965.

https://doi.org/10.1111/j.1529-8817.2012.01173.x previamente considerada una forma de $C$. foeniculacea. Las relaciones PUFA/AGS y PUFA n-6/n-3, el IA y el IT, indicadores de la calidad nutricional de los lípidos en los alimentos, sugieren que las especies de Cystoseira aquí estudiadas pueden ser una fuente interesante de AG alimentarios con efectos benéficos para la salud humana.

Hasta donde sabemos, este trabajo es una de las pocas investigaciones de la composición lipídica y el valor nutricional de las especies de Cystoseira del Mediterráneo, algunas de las cuales son raras y endémicas.

Traducido al español por Claudia Michel-Villalobos

\section{Agradecimientos}

Agradecemos el apoyo financiero del Centro de Actividad Regional para las Áreas Especialmente Protegidas. Los autores agradecen el apoyo técnico brindado por todo el personal del Laboratorio de Biotecnología Vegetal (Instituto Nacional de Ciencias Aplicadas y Tecnología, Túnez, Túnez). Agradecemos a los revisores anónimos los comentarios y las críticas constructivas sobre el manuscrito.

Gómez-Garreta A, Barcelo I-Martí MC, Ribera-Siguán MA, RullLluch J. 2001. Cystoseira C. Agardh. In: Gómez-Garreta A (ed.), Flora Phycologica Iberica. Vol. 1, Fucales. Universidad de Murcia Press, Murcia (Spain), pp. 99-166.

Guiry MD, Guiry GM. 2016. AlgaeBase. [Accessed 05 December 2016] World-wide electronic publication, National University of Ireland, Galway. http://www.algaebase.org.

Hamel G. 1931-1939. Phéophycées de France. [Publisher unknown] Paris (France), 432 pp. + 10 Plates.

Ivanova V, Stancheva M, Merdzhanova A. 2012. Fatty acids composition of macroalgae from Bulgarian Black Sea coast. OUAC 23(1): 35-40. https://doi.org/10.2478/v10310-012-0005-6

Ivanova V, Stancheva M, Petrova D. 2013. Fatty acid composition of Black Sea Ulva rigida and Cystoseira crinita. Bulg. J. Agric. Sci. 19(S1): 42-47.

Khotimchenko SV, Vaskovsky VE, Titlyanova TV. 2002. Fatty acids of marine algae from the Pacific coast of North California. Bot. Mar. 45(1): 17-22. https://doi.org/10.1515/bot.2002.003

Kim MK, Dubacq JP, Thomas JC, Giraud G. 1996. Seasonal variations of triacylglycerols and fatty acids in Fucus serratus. Phytochemistry 43(1): 49-55. https://doi.org/10.1016/0031-9422(96)00243-9

Kovach WL. 2007. MVSP-A Multi-Variate Statistical Package for Windows, ver. 3.1. Kovach Computing Services, Pentraeth (Wales, United Kingdom), 137 pp.

Kumar M, Kumari P, Trivedi N, Shukla MK, Gupta V, Reddy CRK, Jha B. 2011. Minerals, PUFAs and antioxidant properties of some tropical seaweeds from Saurashtra coast of India. J. Appl. Phycol. 23(5): 797-810. https://doi.org/10.1007/s10811-010-9578-7

Kumari P, Bijo AJ, Mantri VA, Reddy CRK, Jha B. 2013. Fatty acid profiling of tropical marine macroalgae: An analysis from chemotaxonomic and nutritional perspectives. Phytochemistry 86: 44-56. https://doi.org/10.1016/j.phytochem.2012.10.015 
Kumari P, Kumar M, Gupta V, Reddy CRK. Jha B. 2010. Tropical marine macroalgae as potential sources of nutritionally important PUFAs. Food Chem. 120(3): 749-757. https://doi.org/10.1016/j.foodchem.2009.11.006

Legendre P, Legendre L. 1998. Numerical Ecology. 2nd English Ed. Elsevier Science BV, Amsterdam (Netherlands), 853 pp.

Nomura M, Kamogawa H, Susanto E, Kawagoe C, Yasui H, Saga N, Hosokawa M, Miyashita K. 2013. Seasonal variations of total lipids, fatty acid composition, and fucoxanthin contents of Sargassum horneri (Turner) and Cystoseira hakodatensis (Yendo) from the northern seashore of Japan. J. Appl. Phycol. 25(4): 1159-1169. https://doi.org/10.1007/s10811-012-9934-x

Pellegrini M, Valls R, Pellegrini L. 1997. Chimiotaxonomie et marqueurs chimiques dans les algues brunes. Lagascalia 19(12): $145-164$.

Pereira H, Barreira L, Figueiredo F, Custódio L, Vizetto-Duarte C, Polo C, Rešek E, Engelen A, Varela J. 2012. Polyunsaturated fatty acids of marine macroalgae: Potential for nutritional and pharmaceutical applications. Mar. Drugs 10(9): 1920-1935. https://doi.org/10.3390/md10091920

Piattelli M. 1990. Chemistry and taxonomy of Sicilian Cystoseira species. New J. Chem. 14: 777-782.

Pohnert G, Boland W. 2002. The oxylipin chemistry of attraction and defense in brown algae and diatoms. Nat. Prod. Rep. 19(1): $108-122$. https://doi.org/10.1039/a806888g

Prevot AF, Mordret FX. 1976. Utilisation des colonnes capillaires de verre pour l'analyse des corps gras par chromotographie en phase gazeuse. Rev. Fr. Corps Gras. 23(7/8): 409-423.

Ragonese C, Tedone L, Beccaria M, Torre G, Cichello F, Cacciola F, Dugo P, Mondello L. 2014. Characterisation of lipid fraction of marine macroalgae by means of chromatography techniques coupled to mass spectrometry. Food Chem. 145: 932-940.

https://doi.org/10.1016/j.foodchem.2013.08.130
Rosell KG, Srivastava LM. 1987. Fatty acids as antimicrobial substances in brown algae. In: Ragan MA, Bird CJ (eds.), Twelfth International Seaweed Symposium. Developments in Hydrobiology, vol. 41. Springer, Dordrecht, (Netherlands), pp. 471-475. https://doi.org/10.1007/978-94-009-4057-4_69

Schnitzler I, Pohnert G, Hay M, Boland W. 2001. Chemical defense of brown algae (Dictyopteris spp.) against the herbivorous amphipod Ampithoe longimana. Oecologia 126(4): 515-521. https://doi.org/10.1007/s004420000546

Simopoulos AP. 2002. The importance of the ratio of omega-6/ omega-3 essential fatty acids. Biomed. Pharmacother. 56(8): $365-379$. https://doi.org/10.1016/s0753-3322(02)00253-6

Simopoulos AP. 2008. The importance of the omega-6/omega-3 fatty acid ratio in cardiovascular disease and other chronic diseases. Exp. Biol. Med. 233(6): 674-688. https://doi.org/10.3181/0711-mr-311

Sokal RR, Michener CD. 1958. A statistical method for evaluating systematic relationships. Univ. Kansas Sci. Bull. 38: 1409-1438.

Ulbricht TLV, Southgate DAT. 1991. Coronary heart disease: seven dietary factors. Lancet 338(8773): 985-992. https://doi.org/10.1016/0140-6736(91)91846-M

Valls R, Piovetti L, Banaigst B, Praud A. 1993. Secondary metabolites from Morocco brown algae of the genus Cystoseira. Phytochemistry 32(4): 961-966. https://doi.org/10.1016/0031-9422(93)85236-k

Vizetto-Duarte C, Pereira H, Bruno de Sousa C, Pilar-Rauter A, Albericio F, Custódio L, Barreira L, Varela J. 2015. Fatty acid profile of different species of algae of the Cystoseira genus: a nutraceutical perspective. Nat. Prod. Res. 29(13): 1264-1270. https://doi.org/10.1080/14786419.2014.992343

Wood JD, Richardson RI, Nute GR, Fisher AV, Campo MM, Kasapidou E, Sheard PR, Enser M. 2004. Effects of fatty acids on meat quality: a review. Meat Sci. 66(1): 21-32. https://doi.org/10.1016/S0309-1740(03)00022-6

Received May 2017, accepted April 2018 